\title{
CORRELATION BETWEEN BODY MASS INDEX AND POSTURAL BALANCE
}

\author{
Julia Greve, Angelica Alonso, Ana Carolina P.G. Bordini, Gilberto Luis Camanho
}

Greve J, Alonso A, Bordini ACPG, Camanho, GL. Correlation between body mass index and postural balance. Clinics. 2007;62(6):717-20.

OBJECTIVE: To evaluate the correlation between body mass index (BMI) and postural balance in unipodal support.

METHOD: 40 males, age $26 \pm 5 \mathrm{yrs}$, body mass $72.3 \pm 11 \mathrm{~kg}$, height $176 \pm 6 \mathrm{~cm}$ and BMI $23.3 \pm 3.2 \mathrm{~kg} / \mathrm{m}^{2}$, were submitted to functional stability tests using the Biodex ${ }^{\circledR}$ Balance System (stability evaluation protocol level 2, which allows an inclination of up to $20^{\circ}$ in the horizontal plane in all directions) to compare stability with BMI.

RESULTS: The general stability index showed a correlation between BMI and postural balance - measured as imbalance $(\mathrm{R}=$ 0.723-dominant side and $\mathrm{R}=0.705$-non-dominant side). The anteroposterior stability index - measured as instability - showed correlations on the dominant $(\mathrm{R}=0.708)$ and non-dominant side $(\mathrm{R}=0.656)$. Lateral instability showed a correlation on the dominant side $(\mathrm{R}=0.721)$ and non-dominant side $(\mathrm{R}=0.728)$. The comparison of the balance indexes for dominant and non-dominant sides showed no statistically significant differences.

CONCLUSION: High BMI demands more displacements to maintain postural balance.

KEYWORDS: Postural balance. Body mass index. Evaluation. Knee joint. Ankle joint.

\section{INTRODUCTION}

Balance is defined as the process that maintains the center of gravity within the body's support base and requires constant adjustments that are provided by muscular activity and joint positioning. Most nervous and musculoskeletal system diseases can alter this balance control. ${ }^{1-3}$ Maintaining postural balance requires sensorial detection of the body's movements, integration of sensory-motor information into the central nervous system and an appropriate motor response. The position of the body in relation to space is determined by visual, vestibular and somaticsensitive functions. Muscular control and dynamic maintenance of balance involve the activity of coordinates of muscular kinetic chains. ${ }^{4-7}$ Adipose tissue accumulation and

Institute of Orthopedics and Traumatology, Hospital das Clinicas, Faculdade de Medicina, Universsidade de São Paulo, Brazil

Email: jgreve@institutoviva.com.br

Received for publication on July 03, 2007

Accepted for publication on August 31, 2007 body mass increases can cause a reduction in the body balance and be a major contributing factor concerning falls, particularly when combined with low muscular mass, which can generate biomechanical failure of muscular responses and loss of stability mechanisms. ${ }^{8-10}$

The objective of this study was to evaluate the correlation between the body mass index (BMI) and postural balance in unipodal support among sedentary male adults.

\section{METHOD}

This is a descriptive observational study carried out in a cross-sectional manner without intervention. 40 male volunteers were evaluated. The inclusion criteria were: a) signing of the free and informed consent statement, b) male sex, c) age between 20 and 40 years, d) no physical activity for a minimum of six months, e) absence of neurological, cardiovascular, metabolic, rheumatic or vestibular diseases, f) no injuries or previous surgery on the legs and g) absence of knee or ankle clinical instability.

The mean age was $26 \pm 5$ years (20-38), mean body mass 
was $72.3 \pm 11 \mathrm{~kg} 9$ (46-107), mean height was $176 \pm 6 \mathrm{~cm}$ (169-186) and mean BMI was $23.3 \pm 3.2 \mathrm{~kg} / \mathrm{m}^{2}$ (18.1-34.1). Thirty-four volunteers $(85 \%)$ had a dominant right limb (kicking side), and six (15\%) had the left limb as such.

The balance test was carried out using the Biodex Balance System (BBS) at the level 2 stability protocol, which allows an inclination of up to $20^{\circ}$ in the horizontal plane in all directions. Stability varies according to the level of resistance (level 8-most stable to level 1-least stable)., ${ }^{211-15}$ Three stability indexes were calculated: anteroposterior stability, lateral stability and general stability (sum of the first two).

\section{Positioning}

Each patient was positioned barefoot on the platform in unipodal support with a $10^{\circ}$ semi-flexed knee. The contra lateral knee remained flexed at $90^{\circ}$ with the patient's arms crossed over his chest, looking at the screen in front. The platform was released, and the patient was instructed to keep himself balanced with the indicator in the center of the target on the screen. When the patient was capable of keeping the indicator in the center of the target on the screen (balance position) without hand support, the position of the feet was recorded using the platform rail (Figure 1).

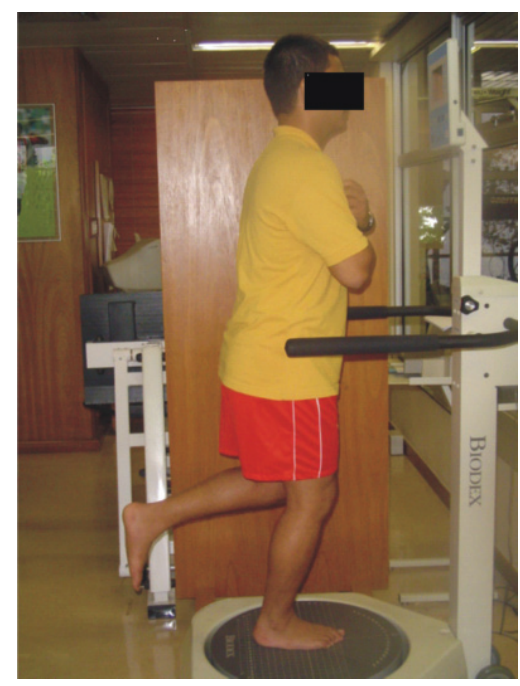

Figure 1 - The Biodex Balance System.

Test

Once the subject was positioned, he was instructed not to move his feet until the end of each measurement. The changes were recorded from the center of the platform. Three measurements were made on each lower limb with a 20-seconds duration separated by one-minute intervals. The result was the arithmetic mean of the three measure- ments, and the equipment supplied this automatically. All tests started with the dominant lower limb.

\section{Statistical analyses}

The Pearson's correlation coefficient was used to compare the BBS results for general stability, anteroposterior stability and lateral stability (mean of three measures) and the BMI index of each volunteer. The level of correlation was considered positive when $\mathrm{R} \geq 0.7$ and negative when $\mathrm{R}<0.7$.

\section{RESULTS}

For the general stability index (GSI), the correlation between BMI and postural balance was $\mathrm{R}=0.723$ on the dominant side (Figure 2) and $\mathrm{R}=0.705$ on the non-dominant side (Figure 3). For the anteroposterior stability index (APSI), the correlation was $\mathrm{R}=0.708$ on the dominant side and $\mathrm{R}=0.656$ on the non-dominant side. For the lateral stability index (MLSI), the correlation was $\mathrm{R}=0.721$ on the dominant side and $\mathrm{R}=0.728$ on the non-dominant side. A comparison between dominant and non-dominant side balance indexes did not show any statistically significant differences.

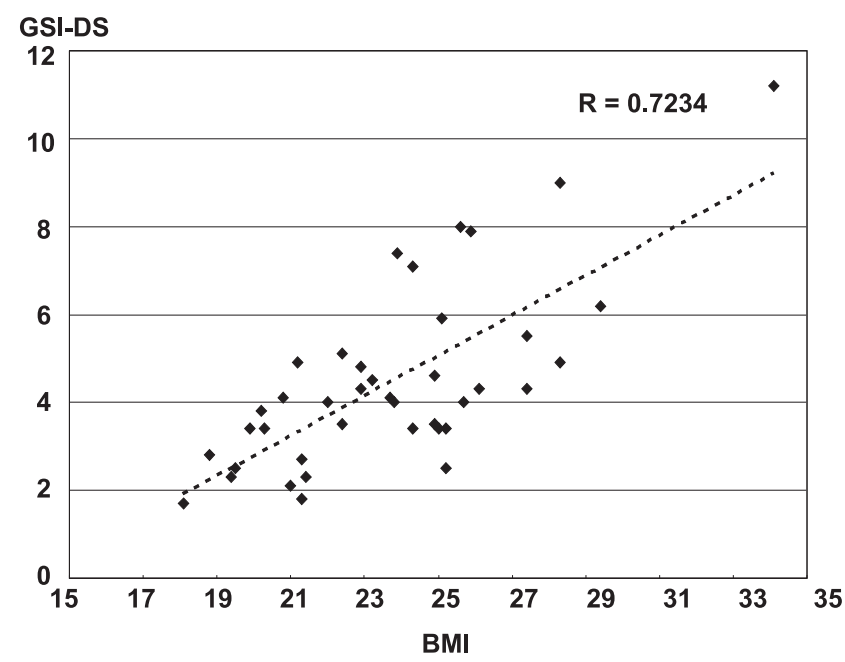

Figure 2 - Correlation between the general stability index on the dominant side (GSI-DS) and the body mass index (BMI).

\section{DISCUSSION}

Studies have demonstrated that the accumulation of fat tissue can reduce body balance and contribute towards falls among extremely obese teenagers and adult patients ${ }^{9,10}$, although further studies are required to investigate the correlation between body mass and balance in the adult population. For this reason, we proposed to study individuals with these characteristics. 


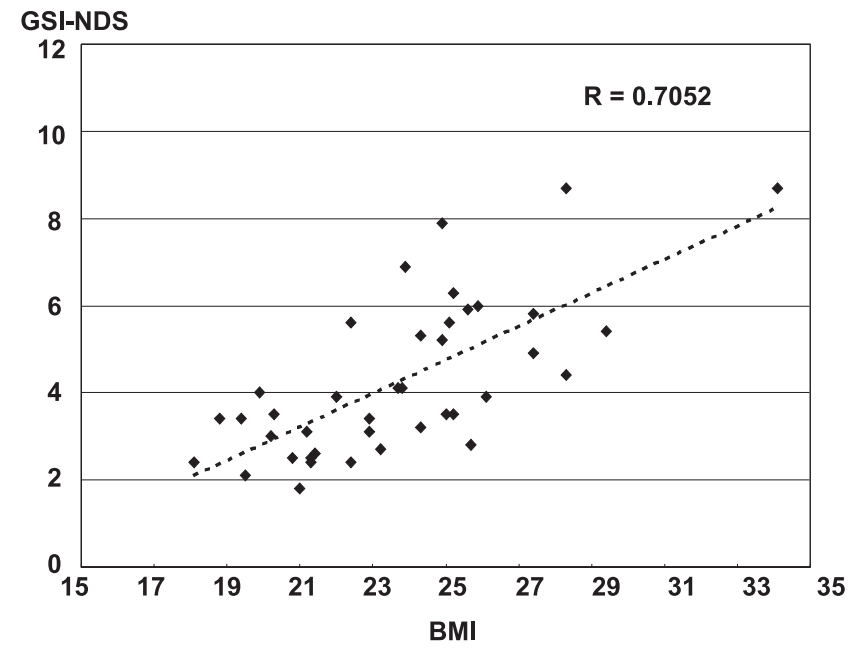

Figure 3 - Correlation between the general stability index on the non-dominant side (GSI-NDS) and the body mass index (BMI).

This study showed a positive correlation between BMI and increased postural instability (greater shifts required in order to keep postural balance) and was in agreement with Hills (1991), who affirmed that excess weight and low level of physical activity increased postural instability. ${ }^{16}$ A $20 \%$ increase in body mass reduces the ability to make adjustments in response to external disturbances in the orthostatic position and increases postural instability. ${ }^{17}$ Patients with BMI greater than $30 \mathrm{~kg} / \mathrm{m}^{2}$ maintain shorter times in balance and longer times unbalanced as compared with nonobese individuals, such that obesity would influence the limits of postural stability. The authors report that obesity (high BMI) will affect the selection of motor strategies employed to maintain postural balance. . $^{8-10}$

Most studies point out the direct relationship between obesity and increased postural instability, but the main question remains, does postural stability change with increased BMI or does the instability appear only in BMI above $30 \mathrm{~kg} /$ $\mathrm{m}^{2}$ ? The present study tried to determine whether an association exists between the quantitative data of postural balance, as represented by the general, anteroposterior and lateral balance indexes measured using the BBS and the BMI in a normal population sample. A correlation between the general balance index was observed on both sides, showing that even though the BMI itself is not a parameter of body composition evaluation, it is possible to infer that the increase of (lean or fat) body mass will interfere with balance.

The correlation between two indexes (stability and BMI) can be criticized due to an increased likelihood of error, although the correlation degree found is moderate to high in all measurements, except for the non-dominant side in lateral stability. This correlation degree allows us to safely infer that the mechanical factor provided by the inertia of the body mass and the effort to balance it against the force of gravity through muscular action is an important element when maintaining posture. ${ }^{11,13}$ The anteroposterior (API) and lateral stability (LSI) index maintained the same correlation degree. Because the correlation between the API and LSI studied is similar, it is not possible to selectively state that either the lateral shift (hip and lower limbs motions) or the anteroposterior shift (trunk motions) is the main factor of increased instability with increasing BMI. The lower relative correlation of the API for the non-dominant side could suggest that the anteroposterior shift strategies (trunk) on this side would be more reflexive and less dependent on body mass, although no statistical differences exist in this index when comparing the dominant and nondominant sides.

These results safely suggest that incorporating the evaluation of body composition in patients with equal BMI, plus the measurement of the shift response time, can help understand and use this correlation in order to prevent falls and other incapacities of obese patients. The measurement of postural balance using the BBS could be questionable, because during the learning strategy (five tries were allowed), the shift time was not measured, which makes this measurement less accurate than stability measurements. Although the BBS functional evaluation could be less accurate than desirable, the correlation between balance measure and BMI associated with body composition could be useful to prescribe and evaluate physical activity program results for obese patients.

Reliable biomechanical evidence exists, showing that postural balance (as expressed by the BBS stability index) will worsen with an increase in body mass as expressed by BMI.

\section{RESUMO}

Greve J, Alonso A, Bordini ACPG, Camanho, GL. Correlação entre índice de massa corpórea e equilíbrio postural. Clinics. 2007;62(6):717-20.

OBJETIVO: Avaliar a correlação entre o índice de massa corporal (IMC) e o equilíbrio postural no suporte unipodal.
MÉTODOS: 40 homens, idade: $26 \pm 5$ anos, massa corporal: $72.3 \pm 11 \mathrm{~kg}$, altura: $176 \pm 6 \mathrm{~cm}$ and IMC: $23.3 \pm$ $3.2 \mathrm{~kg} / \mathrm{m}^{2}$ foram submetidos a testes funcionais de estabilidade corporal usando o Biodex Balance System (protocolo de avaliação nível 2, que permite uma inclinação acima de $20^{\circ}$ no plano horizontal em todas as direções, 
índice que foi comparado ao IMC

RESULTADOS: O índice de estabilidade geral - medido como instabilidade - mostrou correlação entre IMC e o equilíbrio postural ( $\mathrm{R}=0.723$ - lado dominante) e ( $\mathrm{R}=0.705$ - lado não dominante). $\mathrm{O}$ índice de estabilidade ântero-posterior e médio-lateral mostraram correlação no lado dominante $(\mathrm{R}=0.708$ e $\mathrm{R}=0728)$ e não dominante $(\mathrm{R}=0.656$ e $\mathrm{R}=0,721)$. A comparação entre os indices do lado dominante e não dominante não mostrou diferença estatística. CONCLUSÃO: IMC alto exige maior deslocamento corporal para manter o equilíbrio postural.

UNITERMOS: Equilíbrio postural. Indice de massa corporal. Avaliação. Joelho. Tornozelo.

\section{REFERENCES}

1. Arnold BL, Schmitz RJ. Examination of balance measures produced by the Biodex Stability System. J Athl Train. 1998;33:323-7.

2. Barrack RL, Munn BG. Effects of Knee ligament Injury and reconstruction on proprioception. In: Lephart SM, Fu FH, editors. Proprioception and neuromuscular control in joint stability. Philadelphia: Human Kinetics; 2000. p. 197- 212.

3. Battistella LR, Shinzato GT. Retorno à atividade física pós -tratamento do aparelho locomotor. In: Ghoroyeb N, Barros T. O Exercício: por tração fisiológica avaliação médica, aspectos especiais e preventivos. São Paulo: Atheneu; 1999. p. 295-304.

4. Beard D, Refshauge K. Effects of ACL Reconstruction on proprioception and neuromuscular performance. In: Lephart SM, Fu FH, editors. Proprioception and neuromuscular control in joint stability. Philadelphia: Human Kinetics; 2000. p. 213-24.

5. Beynnon BD, Renström PA, Konradsen L, Mlsiqvist LG, Gotlieb D, Dirks M. Validation of techniques to measure knee proprioception. In: Lephart $\mathrm{SM}, \mathrm{Fu} \mathrm{FH}$, editors. Proprioception and neuromuscular control in joint stability. Philadelphia: Human Kinetics; 2000. p. 127-38.

6. Cachupe WJC, Shifflett B, Kahanov L, Wughalter EH. Reliability of Biodex Balance System measures. Meas Phys Educ Exerc Sci. 2001; 5:97-108.

7. Hills AP, Parker AW. Gait characteristics of obese children. Arch Phys Med Rehabil. 1991;72:403-7.

8. Kejonen P, Kauranen K, Vanharanta H. The relationship between anthropometric factors and body-balancing movements in postural balance. Arch Phys Med Rehabil. 2003;84:17-22

9. Ledin T. Odkvist LM. Effects of increased inertial load in dynamic and randomized perturbed posturography. Acta Otolaryngol. 1993;113:249-52.
10. McGraw B, McClenaghan BA, Williams HG, Dickerson J. Gait and postural stability in obese and nonobese prepubertal boys. Arch Phys Med Rehabil. 2000;81:484-9.

11. Maffiuletti NA, Agosti F, Riva D, Resnik M, Lafortuna CL. Postural instability of extremely obese individuals improves after a body weight reduction program entailing specific balance training. J Endocrinol Invest. $2005 ; 28: 2-7$.

12. Perrin DH, Shultz SJ. Models for clinical research involving proprioception and neuromuscular control. In: Lephart SM, Fu FH, editors. Proprioception and neuromuscular control in joint stability. USA: Human Kinetics; 2000. p. $349-62$

13. Riemann BL, Guskiewicz KM. Contribution of the peripheral somatosensory system to balance and postural. In: Lephart SM, Fu FH, editors. Proprioception and neuromuscular control in joint stability. USA: Human Kinetics; 2000. p. 37-51.

14. Riemann BL, Myers JB, Lephart SM. Comparison of the ankle, knee, hip, and trunk corrective action shown during single-leg stance on firm, foam, and multiaxial surfaces. Arch Phys Med Rehabil. 2003;84:90-5.

15. Testerman C, Griend RV. Evaluation of ankle instability using the Biodex Stability System . Foot Ankle Int. 1999;20:317-21.

16. Tookuni KS, Neto RB, Pereira CAM, Souza DR, Greve JMD, Ayala $\mathrm{AD}$. Análise comparativa do controle postural de pacientes com e sem lesão do ligamento cruzado anterior do joelho. Acta Ortop Bras. 2005; $13: 115-9$.

17. Voight M, Blackburn T. Treinamento e testes de propriocepção e equilíbrio após a lesão. In: Ellenbecker TS. Reabilitação dos ligamentos do joelho. São Paulo: Manole; 2002. p. 401-26. 